\title{
TOLERANCE LEVEL OF GRAFTED PAPAYA PLANTS AGAINST PAPAYA DIEBACK DISEASE
}

\author{
HASSAN MOHD-AZHAR ${ }^{1 *}$, JOHARI SARIP ${ }^{1}$, NOOR FAIMAH GHAZALI ${ }^{1}$, \\ MUHAMMAD ZULFA MOHD RAZIKIN ${ }^{1}$ and ABDUL RAZAK MARIATULQABTIAH ${ }^{2}$ \\ ${ }^{1}$ Horticulture Research Centre, MARDI Headquarters, Persiaran MARDI-UPM, \\ 43400 Serdang, Selangor, Malaysia \\ ${ }^{2}$ Faculty of Biotechnology and Biomolecular Sciences, Universiti Putra Malaysia, \\ 43400 Serdang, Selangor, Malaysia \\ *E-mail: mazhar@mardi.gov.my
}

Accepted 16 March 2021, Published online 5 April 2021

\begin{abstract}
Papaya (Carica papaya) cultivars commonly grown in Malaysia, namely Sekaki and Eksotika, are very susceptible to papaya dieback disease (PDD), resulting in reduced production of papayas. As an alternative, grafted papaya seedling using Viorica variety as a highly tolerant rootstock can be introduced to combat PDD. Three grafting combinations of scion/rootstock were used in this study namely Eksotika/Eksotika (E/E), Eksotika/Viorica (E/V) and Viorica/Viorica (V/V). These grafted plants were tested over hot-spot diseased location to evaluate their field tolerance levels against PDD for 14 months of exposure. The occurrence of PDD on grafted papaya plants showed that the disease was mostly found in the E/E combination, with disease severity of $86.7 \%$ and a disease score of 4.34 , whereas the disease severity and disease score of E/V grafting was $71.0 \%$ and 3.55 , respectively. The lowest disease occurrence was recorded on $\mathrm{V} / \mathrm{V}$ plants, with a disease severity of $34.3 \%$ and a disease score of 1.72 . Results showed that $\mathrm{E} / \mathrm{E}$ and $\mathrm{E} / \mathrm{V}$ were highly susceptible, while $\mathrm{V} / \mathrm{V}$ was tolerant against PDD. Therefore, papaya var. Viorica rootstock proved that it could influence the tolerance level of papaya cv. Eksotika scion against PDD.
\end{abstract}

Key words: Carica papaya, Eksotika, grafted papaya, highly tolerant rootstock, Viorica

\section{INTRODUCTION}

Papaya (Carica papaya L.) contains various vitamins and minerals like vitamin $\mathrm{A}$, vitamin $\mathrm{C}$, thiamine, iron, flavonoids, antioxidants and fibre (Ayoola \& Adeyeye, 2010; Boshra, 2013). It contains a special enzyme called papain, which is commonly used as a meat tenderiser or digestive enzyme (Ikram et al., 2015). Papaya also possesses a high content of lycopene and phenolic that is beneficial to the immune system, reduces cancer, heart problems, and cataract (Roowi et al., 2011). The production of papaya is particularly attractive for fruit crop diversification in Malaysia due to the yield potential, high demand in the local market, and its potential for export. However, the Malaysian papaya industry was shocked by a threatening and lethal disease known as papaya dieback disease, which led to a decline in papaya production from 78,000 metric tonnes in 2003

* To whom correspondence should be addressed. to 31,000 metric tonnes in 2013 (FAOSTAT, 2018). The production of papaya fruit was increased from 31,000 metric tonnes in 2013 to 51,000 metric tonnes in 2018 (FAOSTAT, 2018), but the disease still exists and attacks papaya plantations in Malaysia. Two papaya varieties commonly grown in Malaysia are Sekaki and Eksotika, which are very susceptible to this disease (Supian et al., 2017; Sekeli et al., 2018).

Papaya dieback disease (PDD) is the most threatening disease of papaya in Malaysia caused by Erwinia mallotivora bacteria (Mat Amin et al., 2011). This disease is believed to be spread by wind and the entry into the host is usually through injury points. It is also known as bacterial crown rot and bacterial canker, and this disease has been reported in the West Indies, Virgin Islands, Venezuela, Java, Taiwan, and the Mariana Islands (Ollitrault et al., 2005). In Malaysia, it was first detected at Johor in 2003 and spread to five other states within three years (Mat Amin et al., 2011), destroying 800 ha and causing losses of USD 58 million (Maktar et al., 2008). 
The Erwinia pathogen invades and colonises the entire papaya plant including the shoot, leaf, bark and fruit (Sekeli et al., 2018). Plants with PDD infection show greasy, water-soaked lesions, and dark spots on leaves, petioles, trunks, and fruits (Wan et al., 2017). Nishijima (1994) and Mat Amin et al. (2011) explained the details of the symptoms.

Today, farmers are very reluctant to invest in papaya plantations due to the incidence of PDD. Many approaches have been employed to combat the disease, with limited success. Chemical control has been observed as inefficient (Frossard et al., 1985), whereas genetic control was promising as some local populations have shown a high level of resistance/ tolerance, particularly in Guadeloupe, Venezuela, Granada and Trinidad (Webb, 1983; de Lapeyre \& Lyannaz, 1992). The development of new resistant varieties against PDD in Malaysia was accelerated by the discovery of Carica papaya var. Viorica in 2012 (Sekeli et al., 2019). Viorica was mentioned as a high tolerance papaya variety to PDD, which was developed by MARDI's researcher through the selection and purification step using composite controlled pollination (Sarip et al., 2017). Viorica has a moderate eating quality that does not reach consumers and market taste. Nevertheless, this variety has been used as a parent when developing 'Hybrid I' papaya, which was the most resistant to PDD. It also has a high yield, high total soluble solids, and moderate plant height (Azhar et al., 2020).

The main advantage of vegetative propagation is the certainty of retaining the mother plant characteristics (Nguyen \& Yen, 2018). Plant grafting is a strategy for combating soilborne diseases, thus enabling and increasing the production of watermelon and tomato (Cohen et al., 2007; Davis et al., 2008; Bruton et al., 2009; Louws et al., 2010). The grafted papaya trees produce a higher yield, lower fruiting height, and are $100 \%$ hermaphrodite trees with a dwarf stature and long economic life cycle (Allan, 1995; Chong et al., 2008; Mahesh, 2016; Nguyen \& Yen, 2018). Papaya grafting propagation has been successfully applied on some cultivars, and reports have been published on papaya grafting regeneration. For example, Airi et al. (1986) reported that scion shoots from papaya variety $\mathrm{Co}-1$ and Honey Dew were successfully cleft-grafted onto uniformly established seedlings. Chong et al., (2008) also identified $80 \%$ success using the cleft grafting method in 'Eksotika' papaya at the nursery stage.

Cohen et al. (2007) stated that grafting a susceptible scion on a resistant rootstock allows rapid resistance against soilborne diseases. This eliminates the necessity for a prolonged program of breeding. The idea of using resistant rootstock was based on the metabolite translocation and interaction between scion and rootstock (Aloni et al., 2010). Liu et al. (2015) discovered that Cucumis pustalus, a wild Cucumis species, was a suitable rootstock that simultaneously increased the resistance level of cucumber, melon, and watermelon scion to root-knot nematode and fusarium wilt. The same results have been described by McAvoy et al. (2012) and Kunwar et al. (2015) in tomato grafting, which solved multiple soilborne pathogens using the same rootstocks. Thies et al. (2015) also found that grafting root-knot nematode-susceptible scions to resistant rootstocks resulted in low root galling symptom and the highest fruit yield on watermelon. Grafting watermelon on resistant rootstocks can also mitigate the effects of powdery mildew on susceptible scion seedlings (Kousik et al., 2018).

The effects of using highly tolerant rootstock on papaya grafting against PDD pathogen has not yet been reported. Since E. mallotivora is an air-borne pathogen (Graham \& Harrison, 1975) that can strike any part of a papaya tree, it is important to study the potential of the grafting approach to translocate E. mallotivora tolerance from Viorica rootstock to the vulnerable Eksotika scion. The present study identifies the tolerance level of grafted papaya plants against PDD in disease-infected fields.

\section{MATERIALS AND METHODS}

\section{Selection of rootstocks and scions}

The selection of Viorica (Carica papaya) as a rootstock was based on its high tolerance level resulting from glasshouse and 'hot-spot' screening (Sarip et al., 2017). Whereas, the Eksotika variety was selected as the elite scions based on the superior agronomic characters (Simoh \& Sarip, 2015).

\section{Preparation of grafted seedlings}

Three grafting combinations of scion and rootstock were used in this study namely Eksotika onto Eksotika (E/E), Eksotika onto Viorica (E/V), and Viorica onto Viorica (V/V). For one and half months old rootstocks and scions were sterilised using sterilised cotton with $50 \%$ ethanol solution. The scions were cut in a ' $\mathrm{V}$ ' shape using a grafting knife, while the rootstocks plants were cut as vertical sections. Then, the scions were slot into the rootstocks. Elastic parafilm was used to protect and tighten the grafted area. The grafted seedlings were covered and left under transparent plastic for two weeks. Then, the grafted seedlings were placed uncovered for another two weeks for the growing process. The 2.5-month-old of uniform and healthy grafted seedlings were planted on field according to randomised complete block design (RCBD) with three replicates where each replicate contains 30 plants per treatment. The standard agronomic practices, as well 
as pest and disease management as recommended by the Malaysian Agricultural Research and Development Institute (MARDI), were followed (Chan et al., 1994).

\section{Data collection and statistical analysis}

Evaluation of field disease occurrence was conducted at the PDD disease infected area at MARDI Serdang. The grafting combination was screened against PDD to determine the ability of highly tolerance rootstock to induce tolerance towards the highly susceptible elite scion. Data on disease development was recorded monthly on each grafted plant from 5 until 14 months old. Statistical analysis was determined by analysis of variance (ANOVA) using Statistic Analysis Software 9.4 (SAS 9.4). The analysis of treatment means was carried out using Duncan's multiple range test (DMRT).

\section{Assessment of field disease occurrence}

The number of healthy and symptomatic was recorded for each grafted plant. Disease incidence $(\%)$ was valued based on symptoms recorded from each plant sample. The disease incidence (DI) was determined by the following formula (Cooke, 2006):

$$
\text { DI }(\%)=\frac{\text { Number of diseased plants }}{\text { Total number of plants assessed }} \times 100
$$

The incidence score from each plant sample was assessed referring to the score description from Table 1. Meanwhile, the percentage of disease severity (DS, \%) was computed by applying the equation as proposed by Horsfall and Barrat (1945):

$$
\operatorname{DS}(\%)=\frac{\Sigma(\mathrm{a} \times \mathrm{b})}{(\mathrm{N})(\mathrm{Z})} \times 100
$$

$\Sigma(\mathrm{a} \times \mathrm{b})=$ Sum of the symptomatic plant and their corresponding score

$\mathrm{N}=$ Total number of sampled plants

$\mathrm{Z}=$ Highest score

Disease score (mean) was also assessed using the incidence score data recorded from each plant sample. The disease score was measured by the following formula and the tolerance level is listed in Table 2:

$$
\text { Disease score }=\frac{\Sigma(\mathrm{a} \times \mathrm{b})}{\mathrm{N}}
$$

$\Sigma(\mathrm{a} \times \mathrm{b})=$ Sum of the symptomatic plant and their corresponding score $\mathrm{N}=$ Total number of sampled plants

\section{RESULTS}

Papaya trees start flowering when they reach 5 months old while fruits can be harvested as early as 9 months old. The present study found that the overall mean disease incidence of dieback on grafted papaya plants at 9 and 14 months old were $42.3 \%$ and $100.0 \%$, respectively (Figure 1). For the 9-montholds, half of the plants generated from $\mathrm{E} / \mathrm{V}$ and $\mathrm{E} / \mathrm{E}$ grafting were infected by dieback disease. However, only a quarter of all $\mathrm{V} / \mathrm{V}$ grafted plants were infected by the disease at 9 months old. The disease incidence value reached $100 \%$ in each treatment when the age was 14 months old. The percentage of disease incidence until 7 months old (flowering and fruit set stage) of rootstock-tolerance grafted plants $(\mathrm{E} / \mathrm{V}$ and $\mathrm{V} / \mathrm{V})$ was low, but not on rootstocksusceptible E/E. A study by Edelstein et al. (2000) also discovered that the resistance of Sus (Lagenaria siceraria) against Tetranychus cinnabarinus was sustained throughout the flowering and fruit set of the plant. Similar observations have been reported for melon (Mansour \& Karchi, 1990) and maize (Tadmor et al., 1999).

Table 1. Bacterial dieback score description (Lasin et al. 2015; Bakar et al. 2018)

\begin{tabular}{cl}
\hline Score & Description of symptom \\
\hline 0 & No symptom (free from disease). \\
1 & Water-soaked spot on petioles and stems. \\
2 & $\begin{array}{l}\text { Yellowing on leaves. Few black spots on leaves } \\
\text { and fruits. }\end{array}$ \\
3 & $\begin{array}{l}\text { Wilting of the leaf followed by petiole and stem } \\
\text { (flag leaf symptom). Brown lesion on fruits and }\end{array}$ \\
& $\begin{array}{l}\text { canker on stems. } \\
\text { Brown lesion spread to crown and leading to }\end{array}$ \\
& $\begin{array}{l}\text { dieback. Only a few leaves/leafstalks on papaya } \\
5\end{array}$ \\
& $\begin{array}{l}\text { Stems and all plants part become rotten as well } \\
\text { as death of papaya trees (plant death). }\end{array}$ \\
\hline
\end{tabular}

Table 2. Bacterial dieback score and tolerance level (Cueva et al. 2017)

\begin{tabular}{cl}
\hline Disease score & Tolerance level \\
\hline 0 & Resistance \\
$0.1-1.0$ & Highly tolerance \\
$1.1-2.0$ & Tolerance \\
$2.1-3.0$ & Susceptible \\
$3.1-5.0$ & Highly susceptible \\
\hline
\end{tabular}




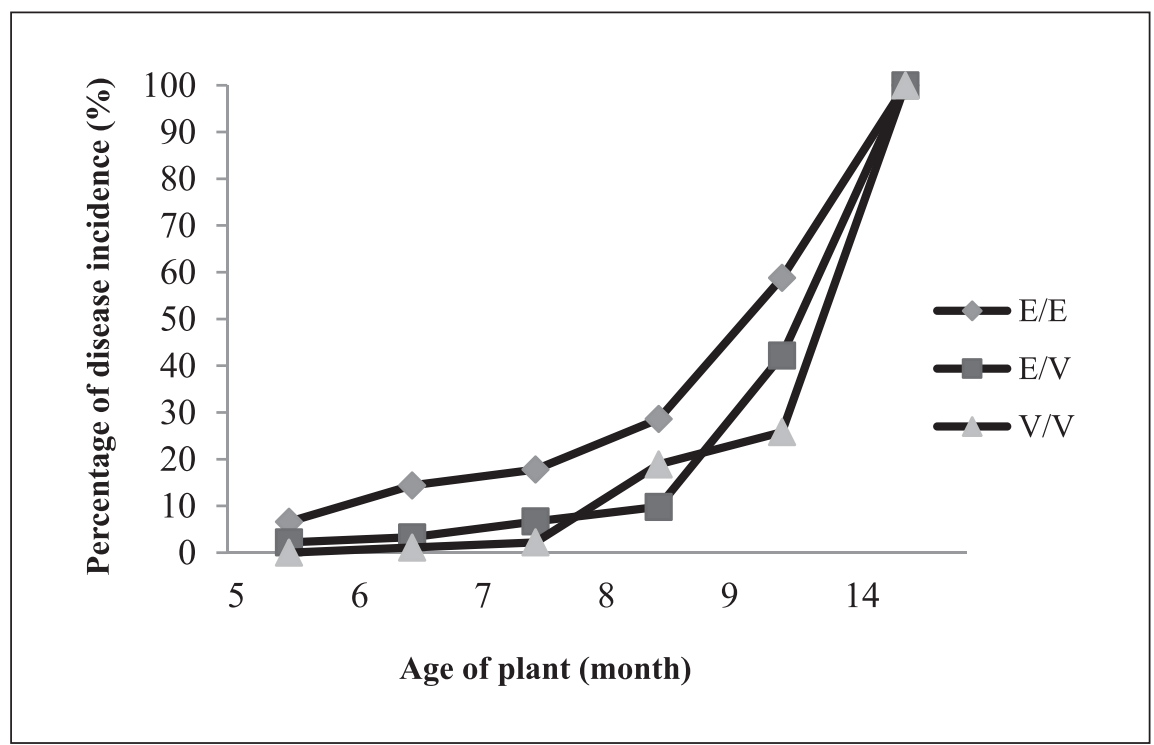

Fig. 1. Disease incidence of papaya dieback on 5-14 months old grafted papaya plants.

Table 3. Analyses of variance for disease severity of papaya dieback on 9 and 14 months old grafted papaya plants

\begin{tabular}{lccc}
\hline \multirow{2}{*}{ Source } & Df & \multicolumn{2}{c}{ Mean Square values } \\
\cline { 3 - 4 } & & $\begin{array}{c}\text { Disease severity } \\
(9 \text { months })\end{array}$ & $\begin{array}{c}\text { Disease severity } \\
(14 \text { months })\end{array}$ \\
\hline Replicate & 2 & $1747.11^{\text {ns }}$ & $476.33^{\text {ns }}$ \\
Treatment & 2 & $936.11^{\text {ns }}$ & $2164.33^{*}$ \\
Error & 4 & 341.78 & 210.67 \\
Total & 8 & & \\
\hline
\end{tabular}

* Significantly different at $p \leq 0.05$.

ns Not significant.

Df Degree of freedom.

Table 3 shows the results of the ANOVA of the three grafting combinations tested in PDD infected area at MARDI Serdang. The mean squares for disease severity on 9 and 14 month old grafted plants are presented in Table 3. Significant differences between treatments were detected in disease severity of 14-month-old plants, but not on 9-month-old plants data. The ANOVA proposed a variation within treatments on disease severity of 14 months old plants, but not on 9-month-old plants. The ANOVA table also showed no significant differences within the replicates for each character analysed, which suggests that the samples used for each replicate were uniformed.

The results on disease severity of papaya dieback on grafted papaya plants are presented in Table 4. Disease severity was relatively low when compared with disease incidence. The overall mean disease severity of papaya dieback on 9 and 14month-old grafted plants was $24.8 \%$ and $64.0 \%$, respectively. The ANOVA with DMRT tests highlighted the highest disease severity was on 9 and 14-month E/E grafted plants, while the lowest severity was found on $\mathrm{V} / \mathrm{V}$ grafted plants at both ages. According to statistical analysis, the severity of dieback disease on 9-month-old grafted plants was not significantly different across each treatment. Meanwhile, the severity of dieback disease in V/V treatment was significantly different compared to two other treatments on 14-month-old grafted plants. The

Table 4. Means of disease severity of papaya dieback on 9 and 14 months old grafted papaya plants

\begin{tabular}{lcc}
\hline \multirow{2}{*}{ Treatment } & \multicolumn{2}{c}{ Disease severity (\%) } \\
\cline { 2 - 3 } & 9 months & 14 months \\
\hline EE & $43.7^{\mathrm{a}}$ & $86.7^{\mathrm{a}}$ \\
E/V & $22.0^{\mathrm{a}}$ & $71.0^{\mathrm{a}}$ \\
V/V & $8.7^{\mathrm{a}}$ & $34.3^{\mathrm{b}}$ \\
\hline
\end{tabular}

*Column means with the same letter are not significantly different at $p \leq 0.05$ according to Duncan's Multiple Range Test (DMRT). 
Table 5. Disease severity reduction, disease score and tolerance level of papaya dieback on 9 and 14 months old grafted papaya plants

\begin{tabular}{|c|c|c|c|c|c|c|}
\hline \multirow{2}{*}{ Treatment } & \multicolumn{2}{|c|}{ Disease severity reduction (\%) } & \multicolumn{2}{|c|}{ Disease score (mean) } & \multicolumn{2}{|c|}{ Tolerance level } \\
\hline & 9 months & 14 months & 9 months & 14 months & 9 months & 14 months \\
\hline E/E & 0 & 0 & 2.19 & 4.34 & Susceptible & Highly susceptible \\
\hline $\mathrm{E} / \mathrm{V}$ & 49.7 & 18.1 & 1.10 & 3.55 & Tolerance & Highly susceptible \\
\hline $\mathrm{V} / \mathrm{V}$ & 80.1 & 60.4 & 0.44 & 1.72 & Highly tolerance & Tolerance \\
\hline
\end{tabular}

percentage of disease severity of 14-month-old grafted plants of all treatments were higher compared to 9-month-old grafted plants, and the best treatment with the lowest percentage of disease severity was $\mathrm{V} / \mathrm{V}$ grafted plants.

The Viorica rootstock reduced the disease severity of PDD by up to $49.7 \%$ on the grafted Eksotika scion compared to the susceptible check E/E grafted plant at 9 months old (Table 5). Similarly, Sakata et al. (2008) reported a high level of powdery mildew reduction in susceptible cucumber scions grafted on resistant rootstocks, which was $15 \%$ to 93\%. A higher percentage of PDD reduction was achieved by high tolerance $\mathrm{V} / \mathrm{V}$ grafted plants, which was $80.1 \%$ when compared to the susceptible E/E grafted plants at 9 months old. The percentage of disease severity reduction decreased on $\mathrm{E} / \mathrm{V}$ and $\mathrm{V} / \mathrm{V}$ grafted plants at 14 months old, which were $18.1 \%$ and $60.4 \%$, respectively.

The disease score and tolerance level data in Table 5 indicate the ability of grafted plants to tolerate when attacked by PDD. The tolerance level on 9-month-old grafted plants was different among the three grafting combinations, which are $\mathrm{V} / \mathrm{V}$ (highly tolerance), E/V (tolerance) and $\mathrm{E} / \mathrm{E}$ (susceptible). Meanwhile, the disease score for 14month-old grafted plant combinations indicates that the $\mathrm{V} / \mathrm{V}$ (1.72) possessed a tolerance level compared to $\mathrm{E} / \mathrm{V}$ (3.55) and $\mathrm{E} / \mathrm{E}$ (4.34) that only showed a highly susceptible level to PDD. This result suggested that Viorica is a high tolerant rootstock and influenced the occurrence level of Eksotika scion to PDD attack. However, the level of tolerance transferred by Viorica was not sufficient to completely prevent PDD from infecting grafted susceptible Eksotika plants. This partial transfer of resistance was similar to field observation on powdery mildew-resistant (Sakata et al., 2006) and papaya ringspot-resistant rootstocks (Webster et al., 2012).

\section{DISCUSSION}

Grafting has been widely used for managing diseases worldwide, but limited work has been done on papaya to test the effectiveness of reducing diseases, especially PDD. The reasons for the lack of grafting in Malaysia are due to issues including the perception of unconfirmed technology, increased costs, and time constraints. Grafting is a common tool for conferring resistance to soil-borne diseases (Edelstein et al., 1999). The list of diseases proven to be reduced by grafting is broad and includes fusarium wilt, root-knot nematodes, powdery mildew, and vine decline in cucurbit, cucumber, melon, watermelon, eggplant and tomato (King et al., 2008; Thies et al., 2015; Kousik et al., 2018). It has been shown that resistant rootstocks physically limit the movement of bacteria from the soil to scion (Grimault et al., 1994). When the resistant rootstock of tomato was used as the scion to graft onto a susceptible rootstock, the resistant plant perished to the soilborne disease of bacterial wilt (Obrero et al., 1971).

The metabolite translocation mechanism happens in plants (Aloni et al., 2010). It can happen concurrently from the lower to the upper part of the plant and vice versa. Since E. mallotivora is an airborne pathogen that attacks mostly the upper part of the papaya plant including leaves, petioles, stems, fruits and crown, it is possible to use Viorica as a high tolerant scion instead of the rootstock. Hence, grafting high tolerant Viorica scion onto superior quality Eksotika rootstocks may generate high quality grafted Viorica plants with high tolerance to PDD.

Papaya fruits are harvested as early as 9 months old. This study shows that the reduction and tolerance level by E/V grafting was higher than E/E grafting at 9 months old. However, the tolerance level of $\mathrm{E} / \mathrm{V}$ grafting was gradually reduced and became similar to E/E grafting at 14 months old. According to Neumann et al. (2009), the plant growth stage can influence the susceptibility or resistance level, which is related to the translocation of plant hormones. Melatonin has been reported to activate plant defence response, thus producing the secondary metabolites against bacterial and fungal plant pathogens (Lee et al., 2014; Qian et al., 2015; Wei et $a l ., 2017)$ found in a large number of plant species including papaya (Nawaz et al., 2016). In this study, it was suspected that the melatonin hormone concentration in Viorica tolerant rootstock decreased 
gradually through time, hence reducing the tolerance level on old E/V grafted plants. A similar observation was found on V/V grafted plants. Studies conducted by Hassan et al. (2018) supported the theory when they found that sesquiterpene (secondary metabolites) compounds concentration in Polygonum minus decreased with time when infected by yeast extract. In-depth studies on the level of melatonin hormone at different plant ages need to be performed to examine this theory further. Nonetheless, based on our results, we suggest that the cultivation of papaya grafted plants with Viorica rootstock and Eksotika scion in disease infected areas have commercial potential for trees between 9 to 12 months of age.

Typically, wild crop species are highly resistant to disease attacks. Many breeders have manipulated this trait to improve disease resistance in crops. Research on grafting of Eksotika papaya onto wild species papaya rootstock such as Vasconcellea cauliflora, Vasconcellea pubescens, Vasconcellea quercifolia and Vasconcellea parviflora to produce PDD-resistant plants is possible. As an example, grafted papaya hybrids and inbreeds onto Vasconcellea cauliflora delayed the symptom expression of papaya ringspot virus (Villegas et al., 1997). In the case of a breeding approach, Drew et al. (2006) found that $75 \%$ of hybrids produced by the interspecific crossing of Carica papaya $\mathrm{X}$ Vasconcellea quercifolia were resistant to papaya ringspot virus type $\mathrm{P}$ and only $25 \%$ produced virus symptoms. Our study shows that the tolerance level of Viorica against PDD might not be strong enough to support Eksotika, which is well-known as a highly susceptible variety, to become a high tolerance grafting plant.

Multiple rootstocks grafting technique is a technique used to accelerate plant growth, yield, and quality, which corresponds to the variety and combination of the rootstock. The growth of durian seedling with multiple rootstocks was better than durian seedling with a single rootstock (Yuniastuti \& Annisa, 2017). The multi rootstock combination of pumpkin and bottle gourd improved the growth potential of watermelon and lower the incidence of fusarium wilt, hence, increasing the yield and quality of fruit (Yaoguo et al., 2014). This multi rootstock approach can be applied on papaya grafting using Viorica and wild species resistant rootstock, possibly enhancing the resistance level of Eksotika grafted plants.

\section{ACKNOWLEDGEMENTS}

This project was funded by the Development Project Grant of $11^{\text {th }}$ Malaysian Plan (P-RH405). The authors would like to acknowledge their deepest thanks to Malaysian Agricultural Research and Development Institute as well as team members for giving generous support to this research.

\section{REFERENCES}

Airi, S.K., Gill, S.S., Singh \& S.N. 1986. Clonal propagation of papaya (Carica papaya L.). Journal of Agriculture Research Punjab, 23: 237-239.

Allan, P. 1995. Propogation of 'Honey Gold' papayas by cuttings. Acta Horticulturae, 370: 99-102.

Aloni, B., Cohen, R., Karni, L., Aktas, H. \& Edelstein, M. 2010. Hormonal signaling in rootstock-scion interactions. Scientia Horticulturae, 127(2): 119126.

Ayoola, P.B. \& Adeyeye, A. 2010. Phytochemical and nutrient evaluation of Carica papaya (pawpaw) leaves. International Journal of Recent Research and Applied Studies, 5(3): 325 328.

Azhar, H.M., Johari, S., Sulastri, J.N., Razali, M., Zulfa, M.M., Faimah, G.N. \& Mariatulqabtiah, A.R. 2020. Field performance of selected papaya hybrids for tolerance to dieback disease. Journal of Tropical Agriculture and Food Science, 48(1): 25-33.

Bakar, N.A., Sohaime, M.Z., Juri, N.M., Badrun, R. \& Sarip, J. 2018. Induction of systemic acquired resistance in papaya by foliar application of $\mathrm{HrpN}$ recombinant protein for increased resistance against papaya dieback pathogen. Current Investigations in Agriculture and Current Research, 2(3): 195-202.

Boshra, V. \& Tajul, A.Y. 2013. Papaya - an innovative raw material for food and pharmaceutical processing industry. Health and the Environment Journal, 4(1): 68-75.

Bruton, B.D., Fish, W.W., Roberts, W. \& Popham, T.W. 2009. The influence of rootstock selection on fruit quality attributes of watermelon. Open Food Science Journal, 3: 15-3.

Chan, Y.K., Raveendranathan, P., Raziah, M.L. \& Choo, S.T. 1994. Penanaman Betik. MARDI Press, Selangor. 59 pp. (Malay). 
Chong, S.T., Prabhakaran, R. \& Lee, H.K. 2008. An improved technique of propagating 'Eksotika' papaya. Acta Horticulturae, 787: 273-276.

Cohen, R., Burger, Y., Horev, C. \& Koren, A. 2007. Introducing grafted cucurbits to modern agriculture: the Israeli experience. Plant Disease, 91(8): 916-923.

Cooke, B.M. 2006. Disease assessment and yield loss. In: The Epidemiology of Plant Diseases. B.M. Cooke, D.G. Jones and B. Kaye (Eds.). Springer, Netherlands. pp. 43-80.

Cueva, F., Waje, A.F., Magdalita, P.M., Justo, V.P., Pathania, N. \& Vawdrey, L. 2017. Evaluation of inoculation techniques to screen for bacterial crown rot resistance in different breeding lines of Carica papaya. Journal of Plant Pathology, 99(2): 355-360.

Davis, A.R., Perkins-Veazie, P., Sakata, Y., LópezGalarza, S., Maroto, J.V., Lee, S.G., Huh, Y.C., Sun, Z., Miguel, A., King, S.R., Cohen, R. \& Lee, J.M. 2008. Cucurbit grafting. Critical Reviews in Plant Sciences, 27(1): 50-74.

De Lapeyre, L.D.B. \& Lyannaz, L.P. 1992. Evidence for resistance sources to bacterial canker in local Guadeloupe populations of Carica papaya. Tropical Fruits Newsletter, 3: 5-6.

Drew, R.A., Siar, S.V., O’brien, C.M., Magdalita, P.M. \& Sajise, A.G.C. 2006. Breeding for papaya ringspot virus resistance in Carica papaya via hybridisation with Vasconcellea quercifolia. Australian Journal of Experimental Agriculture, 46(3): 413-418.

Edelstein, M., Cohen, R., Burger, Y., Shriber, S., Pivonia, S. \& Shtienberg, D. 1999. Integrated management of sudden wilt in melons caused by Monosporascus cannonballus using grafting and reduced rates of methyl bromide. Plant Disease, 83: 1142-1145.

Edelstein, M., Tadmor, Y., Abo-Moch, F., Karchi, Z. \& Mansour, F. 2000. The potential of Lagenaria rootstock to confer resistance to the carmine spider mite, Tetranychus cinnabarinus (Acari: Tetranychidae) in Cucurbitaceae. Bulletin of Entomological Research, 90(2): 113-117.

FAOSTAT. 2018. Food and Agriculture Organisation of the United Nations Statistics Division [WWW Document]. URL http://www.fao.org/faostat/en/ ?\#data/QC (accessed 9.12.20).

Frossard, P., Hugon, R. \& Verniere, C. 1985. The withering of papaya trees in the French Antilles associated with an Erwinia sp. of the group amylovora. Fruits, 40(9): 583-595.

Graham, D.C. \& Harrison, M.D. 1975. Potential spread of Erwinia spp. in aerosols. Phytopathology, 65(6): 739-741.
Grimault, V., Gelie, B., Lemattre, M., Prior, P. \& Schmit, J. 1994. Comparative histology of resistant and susceptible tomato cultivars infected by Pseudomonas solanacearum. Physiological and Molecular Plant Pathology, 44(2): 105-123.

Hassan, M.A., Razak, M.A., Baharom, A.H., Sah, M.S.M. \& Rahman, M.Z.A. 2018. Effects of plant growth regulators on root culture and yeast extract elicitation on metabolite profiles of Polygonum minus. Sains Malaysiana, 47(12): 3085-3094.

Ikram, E.H.K., Stanley, R., Netzel, M. \& Fanning, K. 2015. Phytochemicals of papaya and its traditional health and culinary uses - a review. Journal of Food Composition and Analysis, 41: 201-211.

King, S.R., Davis, A.R., Liu, W. \& Levi, A. 2008. Grafting for disease resistance. HortScience, 43(6): 1673-1676.

Kousik, C.S., Mandal, M. \& Hassell, R. 2018. Powdery mildew resistant rootstocks that impart tolerance to grafted susceptible watermelon scion seedlings. Plant Disease, 102(7): 1290-1298.

Kunwar, S., Paret, M.L., Olson, S.M., Ritchie, L., Rich, J.R., Freeman, J. \& McAvoy, T. 2015. Grafting using rootstocks with resistance to Ralstonia solanacearum against Meloidogyne incognita in tomato production. Plant Disease, 99(1): 119124.

Lasin, S., Sijam, K. \& Awang, Y. 2015. Occurrence and distribution of papaya dieback disease in Peninsular Malaysia. International Journal of Advanced Multidisciplinary Research, 2(7): 4248.

Lee, H.Y., Byeon, Y. \& Back, K. 2014. Melatonin as a signal molecule triggering defence responses against pathogen attack in Arabidopsis and tobacco. Journal of Pineal Research, 57(3): 262268.

Liu, B., Ren, J., Zhang, Y., An, J., Chen, M., Chen, H., Xu, C. \& Ren, H. 2015. A new grafted rootstock against root-knot nematode for cucumber, melon, and watermelon. Agronomy for Sustainable Development, 35(1): 251-259.

Louws, F.J., Rivard, C.L. \& Kubota, C. 2010. Grafting fruiting vegetables to manage soilborne pathogens, foliar pathogens, arthropods and weeds. Scientia Horticulturae, 127(2): 127-146.

Mahesh, G. 2016. Grafted papayas: a boon for dioecious papaya industry. Current Science, 111(8): 1287.

Maktar, N.H., Kamis, S., Mohd Yusof, F.Z. \& Hussain, N.H. 2008. Erwinia papayae causing papaya dieback in Malaysia. Plant Pathology, 57: 774 . 
Mansour, E. \& Karchi, Z. 1990. The evaluation of antibiosis of selected lines for resistance of melon to the carmine spider mite Tetranychus cinnabarinus (Acari: Tetranychidae). Bulletin of Entomological Research, 80: 343-347.

Mat Amin, N., Bunawan, H., Redzuan, R.A. \& Jaganath, I.B.S. 2011. Erwinia mallotivora sp., a new pathogen of papaya in Peninsular Malaysia. International Journal of Molecular Sciences, 12(1): 39-45.

McAvoy, T., Paret, M., Freeman, J.H., Rideout, S. \& Olson, S.M. 2012. Evaluation of grafting using hybrid rootstocks for management of bacterial wilt in field tomato production. HortScience, 47: 621-625.

Nawaz, M.A., Huang, Y., Bie, Z., Ahmed, W., Reiter, R.J., Niu, M. \& Hameed, S. 2016. Melatonin: current status and future perspectives in plant science. Frontiers in Plant Science, 6: 1230.

Neumann, K.H., Kumar, A. \& Imani, J. 2009. Plant Cell and Tissue Culture - A Tool in Biotechnology: Basics and Application. Springer-Verlag, Berlin Heidelberg. 332 pp.

Nguyen, V.H. \& Yen, C.R. 2018. Rootstock age and grafting season affect graft success and plant growth of papaya (Carica papaya L.) in greenhouse. Chilean Journal of Agricultural Research, 78(1): 59-67.

Nishijima, K.A. 1994. Internal yellowing. In: Compendium of tropical fruit diseases. R.C. Ploetz, G.A. Zentmyer, W.T. Nihijima, K.G. Rohrbach and H.D. Ohr (Eds.). APS Press, Minnesota. pp. 56-70.

Obrero, F.P., Aragaki, M. \& Trujillo, E.E. 1971. Tomato bacterial wilt: inoculation of susceptible scions grafted to resistant rootstock. Plant Disease Reporter, 55: 521-522.

Ollitrault, P., Bruyère, S., Ocampo, J., de Lapeyre, L., Gallard, A., Argoud, L., Duval, M.F., Coppens d'Eeckenbrugge, G. \& Le Bellec, F. 2005. Papaya breeding for tolerance to bacterial decline (Erwinia sp.) in the Caribbean Region. Acta Horticulturae, 740: 79-91.

Qian, Y., Tan, D.X., Reiter, R.J. \& Shi, H. 2015. Comparative metabolomic analysis highlights the involvement of sugars and glycerol in melatonin-mediated innate immunity against bacterial pathogen in Arabidopsis. Scientific Reports, 5(1): 1-11.

Qin, Y., Yang, C., Xia, J., He, J., Ma, X., Yang, C., Zheng, Y., Lin, X., He, Z., Huang, Z. \& Yan, Z. 2014. Effects of dual/threefold rootstock grafting on the plant growth, yield and quality of watermelon. Notulae Botanicae Horti Agrobotanici Cluj-Napoca, 42(2): 495-500.
Sakata, Y., Sugiyama, M., Ohara, T. \& Morishita, M. 2006. Influence of rootstocks on the resistance of grafted cucumber (Cucumis sativus L.) scions to powdery mildew (Podosphaera xanthii U. Braun and N. Shishkoff). Journal of the Japanese Society for Horticultural Science, 75: 135-140.

Sakata, Y., Ohara, T. \& Sugiyama, M. 2008. The history of melon and cucumber grafting in Japan. Acta Horticulturae, 767: 217-228.

Sarip, J., Nur Sulastri, J., Sanimah, S., Salehudin, M.R., Razali, M., Noor Faimah, G., Noraisah, R., Puteri, D.E.Z., Fauzam, C.H. \& Zulfa, M.R. 2017. Viorica: A promising rootstock in producing highly tolerance grafted papaya against papaya dieback disease. Transactions of the Malaysian Society of Plant Physiology, 25: 56-60.

Sekeli, R., Hamid, M.H., Razak, R.A., Wee, C.Y. \& Ong Abdullah, J. 2018. Malaysian Carica papaya L. var. Eksotika: Current research strategies fronting challenges. Frontiers in Plant Science, 9: 1380.

Sekeli, R., Nazaruddin, N.H., Tamizi, A.A., Amin, N.M., Wee, C.Y., Sarip, J., Abdullah, N., Saidi, N.I., Razak, R.A. \& Zulkifli, Z. 2019. Enhancing Eksotika papaya resistance to dieback disease through quorum quenching. Journal of Tropical Plant Physiology, 11(1): 1-9.

Simoh, S. \& Sarip, J. 2015. Metabolomic analysis of Carica papaya variety Eksotika and Sekaki. Journal of Tropical Agriculture and Food Science, 43(2): 103-117.

Supian, S., Saidi, N.B., Wee, C.Y. \& Abdullah, M.P. 2017. Antioxidant-mediated response of a susceptible papaya cultivar to a compatible strain of Erwinia mallotivora. Physiological and Molecular Plant Pathology, 98: 37-45.

Roowi, S., Azidin, F.M., Sarip, J. \& Said, M. 2011. Antioksidan di dalam betik. Agromedia, June, pp. 12.

Tadmor, Y., Lewinsohn, E., Abu-Moch, E., Bar-Zur, A. \& Mansour, E. 1999. Antibiosis of maize inbred lines to the carmine spider mite, Tetranychus cinnabarinus (Acari: Tetranychidae). Phytoparasitica, 27: 35-41.

Thies, J.A., Ariss, J.J., Hassell, R.L., Buckner, S. \& Levi, A. 2015. Accessions of Citrullus lanatus var. citroides are valuable rootstocks for grafted watermelon in fields infested with root-knot nematodes. HortScience, 50(1): 4-8.

Villegas, V.N., Bajet, N.N., Laureana, A.A. \& Garcia, R.N. 1997. Delayed PRSV-P (papaya ringspot potyvirus) symptom expression among asexually propagated papaya. Philippine Journal of Crop Science, 22(1): 58. 
Wan, T.C., Jualang, A.G., Markus, A., Jugah, K., Evenni, P. \& Khim, P.C. 2017. First report of Erwinia psidii associated with papaya dieback disease in Malaysia. Malaysian Journal of Microbiology, 13(1): 20-25.

Webb, R. 1983. Variations in response of 24 papaya varieties infected with bacterial canker. Phytopathology, 73(5): 811.

Webster, C.G., Kousik, C.S., Hassell, R.L., Ling, K.S., Turechek, W.W. \& Adkins, S. 2012. Virus movement within grafted watermelon plants. Phytopathology, 102(4): 133.

Wei, Y., Hu, W., Wang, Q., Zeng, H., Li, X., Yan, Y., Reiter, R.J., He, C. \& Shi, H. 2017. Identification, transcriptional and functional analysis of heatshock protein 90s in banana (Musa acuminata L.) highlight their novel role in melatoninmediated plant response to fusarium wilt. Journal of Pineal Research, 62(1).
Yaoguo, Q., Cuiqin, Y., Jialong, X., Jing, H., Xiaoli, M., Chuanyang, Y., Yangxia, Z., Xia, L., Zhongqun, H., Zhi, H. \& Zesheng, Y. 2014. Effects of dual/threefold rootstock grafting on the plant growth, yield and quality of watermelon. Notulae Botanicae Horti Agrobotanici Cluj-Napoca, 42(2): 495-500.

Yuniastuti, E. \& Annisa, B.A. 2017. Approach grafting of durian seedling with variation of multiple rootstock. Bulgarian Journal of Agricultural Science, 23(2): 232-237. 
